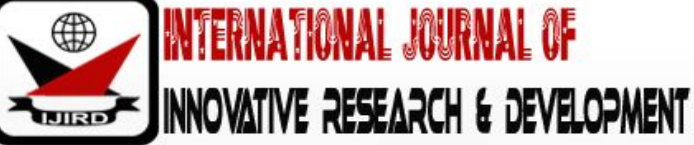

ISSN 2278 - 0211 (Online)

\section{Relationship between Election Phase Processes and Political Stability in the East African Community States}

Rwigema Pierre Celestin
Ph. D. Student, Leadership and Governance, Department of Leadership and Governance
Jomo Kenyatta University of Agriculture and Technology, Kigali, Rwanda
Dr. Mike A. Iravo
Grincipal, Department of Business, Jomo Kenyatta University of Agriculture and Technology, Kenya
Gregory Namusonge
Professor, Department of Business, Jomo Kenyatta University of Agriculture and Technology, Kenya

\begin{abstract}
:
The general objective of the study was to examine the role of political leadership in electoral process and political stability in the East African Community States. To achieve the general objective this study was to assess the relationship between election phase processes and political stability in the East Africa Community States. This study adopted a quantitative approach of both descriptive and correlation designs. The target population consisted of 123 individuals working within the electoral commissions of different EAC Countries and the EAC Legislative Assembly. Primary data was collected using self-administered questionnaire. The study used primary data, which was collected using questionnaires. The questionnaires were both open and close ended. The study used email, phone calls and meeting procedure with the targeted respondent in EACCountries and the EAC Legislative Assembly to follow up. Data collected from the field were coded, cleaned and categorized according to questionnaire items. A pilot test was conducted to detect weaknesses in design and instrumentation. The gathered data was analyzed using computer aided IBM Statistical Package for Social Sciences (SPSS) version 21 premium. Both descriptive and inferential statistics was used to analyze the data collected. Descriptive statistics involved computation of mean scores, standard deviation, percentages, cross tabulation and frequency distribution which described the demographic characteristics of the organization and the respondents. Inferential statistics was used to determine the relationships and significance between independent and dependent variable. Correlation and linear regression were used to analyze the data with F-test being applied to the test hypothesis at $5 \%$ level of significance. Content analysis was used for the qualitative data. The data was presented using tables, graphs and charts. The data was presented using tables, graphs and charts. Regression analysis was performed in order to determine whether the independent variable, election phase processes could be reliable for explaining the change in the dependent variable, political stability in East Africa region. The coefficients obtained indicate that the correlation coefficient $(R)$ between the independent variable and the political stability was 0.663 which is a positive correlation relationship. A coefficient of determination $\left(\mathrm{R}^{2}\right)$ of 0.44 , which means that this variable alone can explain up to $44.0 \%$ of the variations in the dependent variable, political stability. Based on the empirical results presented in alternative Hypothesis $\mathrm{H} 2$ is accepted and the null Hypothesis (H02) is rejected and a conclusion reached that, at 5\% level of significance, election phase processes significantly influence the political stability. Recommendation for improvement can be drawn from the study conclusions; moderating role of political leadership was reported to be persistent in the study area, the government should consider extending the law branch to the rest of the east Africa community state through screening, supporting of law moderation groups locked out by stringent east Africa community state program approval procedures in order to ensure that most people are reached out in the program.
\end{abstract}

Keywords: Election process, political leadership, political stability, east African community states

\section{Background to the Study}

All most all African Countries including the East African Community member countries have multiparty democracy and have been holding elections regularly since independence (Odhiambo, 2009). However, the process of holding elections has not been smooth, with the losers contesting the outcome despite the fact that the elections have been conducted within the legal framework and in line with international, African and regional treaties and standards. This section focuses on some pertinent issues related to the election process that are expected to be applied to make the election process more reliable: 


\subsection{Election Administration}

Elections are generally managed by the Independent Electoral Bodies (IEB) established in the constitution or under the Acts of Parliament. The Commissions are headed by commissioners, with one serving as chairperson. The Commissioners are appointed through an inclusive process that involves all political parties registered with the Commission (Bratton, M. (2008). In many cases, the impartiality and effectiveness of the IEBs has always raised concern that they tend to give preferential treatment to the ruling party leading to major lapses in their effectiveness. The ineffectiveness of the IEC can also be attributed to lack of capacity and poor competence of IEB personnel due to lack of training for the job. Emphasis of IEB independent in terms of law in most cases is not mirrored in their practice as they serve mainly to 'promote' the interests of the ruling party (Obi, 2008).

IEB funding has also been adequate in many African Countries including the East African Community. The Ministry in charge of the treasury should always strive to provide even contingency budgets for the Electoral Bodies whenever the need arises so that the bodies do not depend on non-governmental organizations for their budget. Challenges concerning mechanisms for ensuring freeness and fairness in political campaigns also need to be addressed in advance and ensure that there is a binding Code of Conduct that all participating political parties and independent candidates are subjected to.

This Code of Conduct gives the IEB powers to discipline and even to take to court, individuals and political parties that are deemed to be in breach of it. The objective of the Code is to promote conditions conducive to conducting free and fair elections within a tolerant and democratic environment in which political parties can carry out their activities without fear, coercion, intimidation, and reprisals. The code is expected to give IEB legal powers that would ensure that campaigns are free and fair. Access to state resources which gives the ruling party advantage over its competitors has also remained a thorny issue. This is because members of the opposition hardly have the resources to fund their political campaigns and the private sector that could help to solve the problem is also curtailed in many cases.

\subsection{The Use of State Resources in Campaigns}

The law in some countries allows incumbent Ministers unrestricted use of state vehicles and IECs has no control over this imbalance, as it is allegedly the norm all over the world. Another example relates to allegations of food aid being strategically distributed to constituencies a few days before the elections. Discriminatory use of public resources by ordinary ruling-party members for their campaigns is also common (Ukase, 2015). There is an emerging trend where some of the principal secretaries, though not legally allowed to do so like incumbent Ministers, are openly using public resources to campaign for the ruling party's candidacy in their respective constituencies as well as unlimited access to the state media throughout the year, while their parties are only allowed a few brief slots paid for by the IEC on national radio and television, barely about a month before elections.

It is common for the ruling party, on occasion, covertly and overtly abuses the law to hinder legitimate activities of the opposition parties. In many cases, the ruling party has, through the police, obscured the marches of the opposition from the public eye by imposing awkward and isolated routes for such marches.

\subsection{Statement of the Problem}

Globally, electoral process is an important role in shaping the political stability in any given country. Violating the stipulated code of conduct of the electoral process is dangerous to both the economy and the political stability of a country. This is potential in situations where polls are subject to manipulation or conducted by a biased source hence distortion of poll results. It is well recognized under international law that any limitation placed on freedom of expression must remain within strictly-defined parameters.

For example this is evidenced by the 2007 post-election violence in Kenya that left more than 1,500 Kenyans killed, 1,133 casualties, over 350,000 internally displaced persons, approximately 2,000 refugees, destruction of 117,216 private property and 491 government owned property, around 42,000 houses and many businesses looted and destroyed, gang rapes, and destruction of the railway line (Kioko, 2010).The lessons learnt however did not live long to help Kenya organize free and fair elections in the 2017 presidential elections.

The situation in Burundi has progressively deteriorated since 25 April 2015. According to the armed conflict location and event data set country report on Burundi crisis (2016), the Burundi political conflict reported fatality count of 1,155 between 26 April 2015 and 25 April 2016. At least 690 of the reported dead (or approximately 60\%) are civilians. More than 260,000 people have reportedly fled outside Burundi and thousands have disappeared without trace: approximately 137,000 Burundian refugees have crossed into Tanzania, 77,000 into Rwanda, 23,000 into Uganda, and 22,000 into the Democratic Republic of Congo (DRC) (UNHCR, 29 April 2016).

According to the Commonwealth Observer Group report on Uganda Presidential and Parliamentary Elections in 2011 and 2016 respectively a number of irregularities in the electoral processes have consistently been noted and they include; lack of a level playing field; abuse of incumbency , the 'commercialization of politics', the lack of campaign finance regulations; the lack of a Political Parties Code of Conduct; issues with regard to the lack of independence of the Electoral Commission and its poor management of the process.

Quantitative cross-national research on the principal manifestations of political instability coups and civil wars has consistently shown that economic conditions are the best predictors in Africa and other developing regions, (Fearon \& Laitin, 2013), (Miguel et al 2014) and (McGowan, 2014). Although these empirical analyses acknowledge that the weakness of political institutions contribute to the region's volatility, they do not explicitly bring out the factors related to electioneering and leadership positions as possible contributors and the chief strategy used by most African leaders to buy off rivals and reward their followers. 
This is attributable to difficulties in operationalization and measurement of indicators of the electoral processes and leadership. From the review it is also worth noting that a few studies have determined the electoral processes.

\subsection{Objectives of the Study}

\subsubsection{General Objective}

The general objective of the study was to examine the role of political leadership in electoral process and political stability in the East African Community States.

\subsubsection{Specific Objectives}

This study specifically sought to:

- To assess the relationship between election phase processes and political stability in the East African Community States.

\subsection{Research Questions}

The following research questions guided the study;

- How does election phase processes affect the political stability in the East African Community States?

1.6. Research Hypotheses

- Ho2: There is no significant relationship between election phase and political stability in the East African Community States;

\section{Conceptual Framew ork}

The election processes stand out as the independent variable which has effect on the political stability of the East African Community States. The study considered the following indicators of the electioneering processes: pre-election phase processes, election process and the post-election processes which help in tracking progress, reviewing of results and modifying plans to harmonization of the political system in the EAC States. Political stability is thus, dependent on the design and prudent implementation of the harmonized electoral process that applied to all the EAC States. The variables and their relationship are shown in the Figure 1 below

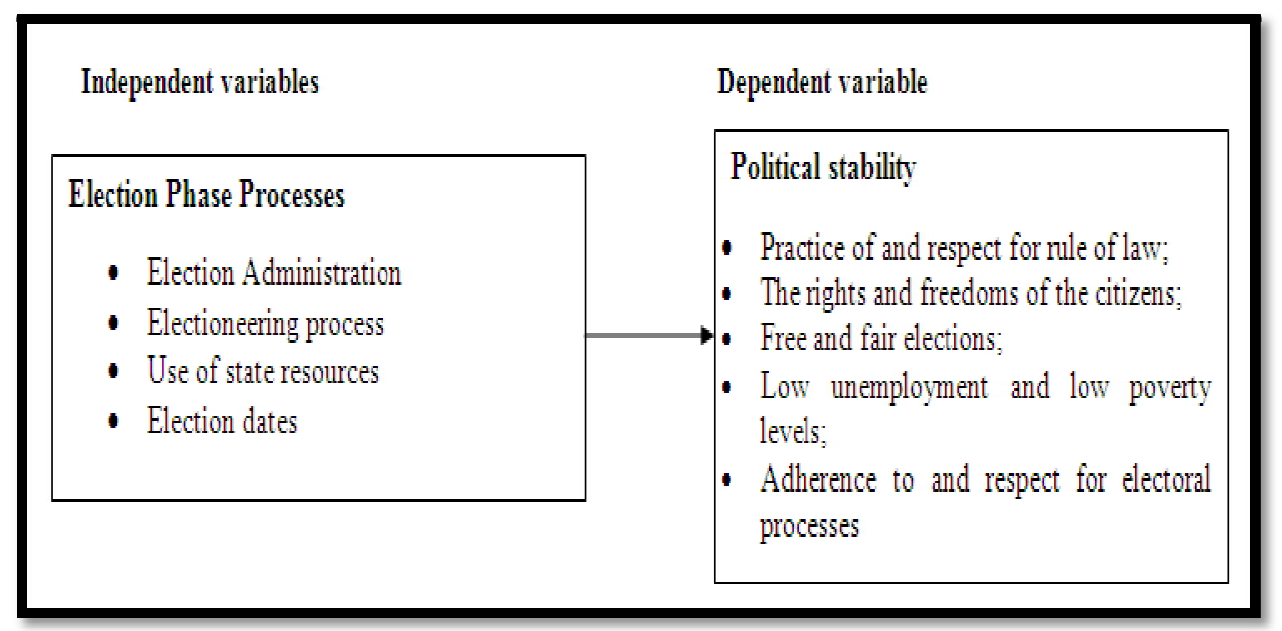

Figure 1: Conceptual Framework

\section{Research design}

This study adopted a quantitative approach of both descriptive and correlation designs. The designs suit this study since they enabled the researcher to establish the effect of the electoral processes on political stability. The designs further provided opportunity for the status of electoral processes in the EAC region to be studied without affecting the research context and also ensure that the data collection procedures are fairly explicit in terms of adequately addressing the study objectives. Quantitative data was captured through the use of a questionnaire.

\subsection{Target Population}

The target population consisted of 123 individuals working within the electoral commissions of the different EAC Countries and the EAC Legislative Assembly. Target population refers to the entire group of individuals or objects to which researchers are interested in generalizing the conclusions. The target population usually has varying characteristics and it is also known as the theoretical population (Kothari, 2011). 


\section{Regression Analysis}

\subsection{Descriptive Statistics Results for Election Phase Processes}

The study found out that out of the 83 respondents, $6.0 \%$ strongly disagreed that the election administration has been effective and efficient as exercised in the EAC States to ensure political stability, 13.3\% disagreed, 13.3\% somehow agreed while $24.1 \%$ agreed that the Election administration has been effective and efficient as exercised in the EAC States to ensure political stability lastly $43.4 \%$ strongly agreed that election administration has been effective and efficient as exercised in the EAC States to ensure political stability.

In addition The study found out that out of the 83 respondents, 9.6\% strongly disagreed that the EAC laws and regulations on administration are adequate in do not need any harmonization to ensure political stability, $14.5 \%$ had disagreed that the EAC laws and regulations on administration are adequate in do not need any harmonization to ensure political stability, $16.9 \%$ had somehow agreed that the EAC laws and regulations on administration are adequate in do not need any harmonization to ensure political stability $37.7 \%$ strongly agreed that The EAC laws and regulations on administration are adequate in do not need any harmonization to ensure political stability.

The study found out that out of the 83 respondents, $2.4 \%$ strongly disagreed that there is no need to harmonize the implementation of the existing laws and regulations on election administration in the EAC States to ensure political stability, $27.7 \%$ disagreed with the statement that there is no need to harmonize the implementation of the existing laws and regulations on election administration in the EAC States to ensure political stability, 25.3\% somehow agreed that there is no need to harmonize the implementation of the existing laws and regulations on election administration in the EAC States to ensure political stability, $26.5 \%$ agreed that there is no need to harmonize the implementation of the existing laws and regulations on election administration in the EAC States to ensure political stability, there is no need to harmonize the implementation of the existing laws and regulation $18.1 \%$ strongly agreed that there is no need to harmonize the implementation of the existing laws and regulations on election administration in the EAC States to ensure political stability.

The study found out that out of the 83 respondents, $18.1 \%$ had strongly disagreed that electioneering process has been free and fair as exercised in the EAC States to ensure political stability, $18.1 \%$ had disagreed that electioneering process has been free and fair as exercised in the EAC States to ensure political stability, 25.3\% had somehow agreed that Electioneering process has been free and fair as exercised in the EAC States to ensure political stability, 13.3\% had agreed that electioneering process has been free and fair as exercised in the EAC States to ensure political stability, 25.3\% strongly agreed that Electioneering process has been free and fair as exercised in the EAC States to ensure political stability.

The study found out that out of the 83 respondents, 19.3\% had strongly disagreed that the EAC laws and regulations on the electioneering process are adequate in do not need any harmonization to ensure political stability, $20.5 \%$ had disagreed that the EAC laws and regulations on the electioneering process are adequate in do not need any harmonization to ensure political stability, $24.1 \%$ had somehow agreed that the EAC laws and regulations on the electioneering process are adequate in do not need any harmonization to ensure political stability, $21.7 \%$ had agreed that The EAC laws and regulations on the electioneering process are adequate in do not need any harmonization to ensure political stability, $14.5 \%$ strongly agreed that The EAClaws and regulations on the electioneering process are adequate in do not need any harmonization to ensure political stability.

The study found out that out of the 83 respondents, $6.0 \%$ had strongly disagreed that there is no need to harmonize the implementation of the existing laws and regulations on electioneering process in the EAC States to ensure political stability, $14.5 \%$ had disagreed that there is no need to harmonize the implementation of the existing laws and regulations on electioneering process in the EAC States to ensure political stability, 32.5\% had somehow agreed that there is no need to harmonize the implementation of the existing laws and regulations on electioneering process in the EAC States to ensure political stability, $14.5 \%$ had agreed that there is no need to harmonize the implementation of the existing laws and regulations on electioneering process in the EAC States to ensure political stability, $32.5 \%$ strongly agreed that there is no need to harmonize the implementation of the existing laws and regulations on electioneering process in the EAC States to ensure political stability The study found out that out of the 83 respondents, $2.4 \%$ had strongly disagreed that the Use of state resources for political activities is effectively controlled in the EAC States during elections to ensure political stability, $21.7 \%$ had disagreed that the use of state resources for political activities is effectively controlled in the EAC States during elections to ensure political stability, 22.9\% had somehow agreed that the use of state resources for political activities is effectively controlled in the EAC States during elections to ensure political stability, $34.9 \%$ had agreed that the use of state resources for political activities is effectively controlled in the EAC States during elections to ensure political stability $18.1 \%$ strongly agreed that use of state resources for political activities is effectively controlled in the EAC States during elections to ensure political stability

The study found out that out of the 83 respondents, 18.1\% had strongly disagreed that the EAC laws and regulations on the use of state resources are adequate in do not need any harmonization to ensure political stability, $18.1 \%$ had disagreed that the EAC laws and regulations on the use of state resources are adequate in do not need any harmonization to ensure political stability, $13.3 \%$ had somehow agreed that the EAC laws and regulations on the use of state resources are adequate in do not need any harmonization to ensure political stability, $18.1 \%$ had agreed that the EAC laws and regulations on the use of state resources are adequate in do not need any harmonization to ensure political stability, $32.5 \%$ strongly agreed that the EAC laws and regulations on the use of state resources are adequate in do not need any harmonization to ensure political stability. 
Table 4.10 shows that out of the 83 respondents, $4.8 \%$ had strongly disagreed that there is no need to harmonize the implementation of the existing laws and regulations on the use of state resources in political activities in the EAC States to ensure political stability, $16.9 \%$ had disagreed that there is no need to harmonize the implementation of the existing laws and regulations on the use of state resources in political activities in the EAC States to ensure political stability, 27.7\% somehow agreed that there is no need to harmonize the implementation of the existing laws and regulations on the use of state resources in political activities in the EAC States to ensure political stability, 36.1\% agreed that there is no need to harmonize the implementation of the existing laws and regulations on the use of state resources in political activities in the EAC States to ensure political stability, $14.5 \%$ strongly agreed that there is no need to harmonize the implementation of the existing laws and regulations on the use of state resources in political activities in the EAC States to ensure political stability.

The study found out shows that out of the 83 respondents, 3.6\% had strongly disagreed that election dates are effective for each of the EAC States during elections as they are to ensure political stability, $26.5 \%$ had somehow agreed election dates are effective for each of the EAC states during elections as they are to ensure political stability, $20.5 \%$ agreed that election dates are effective for each of the EAC States during elections as they are to ensure political stability $31.3 \%$ strongly agreed that election dates are effective for each of the EAC States during elections as they are to ensure political stability.

The study found out that out of the 83 respondents, $22.9 \%$ had strongly disagreed that the EAC laws and regulations on election dates are adequate in do not need any harmonization to ensure political stability, $20.5 \%$ had disagreed the EAC laws and regulations on election dates are adequate in do not need any harmonization to ensure political stability, $21.7 \%$ had somehow agreed the EAC laws and regulations on election dates are adequate in do not need any harmonization to ensure political stability, $18.1 \%$ had agreed that the EAC laws and regulations on election dates are adequate in do not need any harmonization to ensure political stability. 16.9\% that the EAC laws and regulations on election dates are adequate in do not need any harmonization to ensure political stability.

The study found out that out of the 83 respondents, $22.9 \%$ strongly disagreed there is no need to harmonize the implementation of the existing laws and regulations on election dates in the EAC States to ensure, $21.7 \%$ disagreed that there is no need to harmonize the implementation of the existing laws and regulations on election dates in the EAC states to ensure, $25.3 \%$ had somehow agreed that there is no need to harmonize the implementation of the existing laws and regulations on election dates in the EAC states to ensure, $15.7 \%$ agreed there is no need to harmonize the implementation of the existing laws and regulations on election dates in the EAC States to ensure 14.5\% that there is no need to harmonize the implementation of the existing laws and regulations on election dates in the EAC States to ensure.

\subsection{Election Phase Processes and Political Stability}

This section presents the Coefficients of, the line of best fit, Regression Analysis and ANOVA for election phase processes.

\subsubsection{Coefficients of Election Phase Processes}

The coefficients of election phase processes are presented in Table 1 which indicate that the model has a significant $p$-value $=000$. The study at $95 \%$ confidence interval solved the second research question by indicating that the variable election phase processes is statistically significant in the political stability.

\begin{tabular}{|c|c|c|c|c|c|c|}
\hline Model & & \multicolumn{2}{|c|}{$\begin{array}{c}\text { Unstandardized } \\
\text { Coefficients }\end{array}$} & $\begin{array}{c}\text { Standardized } \\
\text { Coefficients }\end{array}$ & T & Sig. \\
\hline & & $\mathrm{B}$ & Std. Error & Beta & & \\
\hline 1 & (Constant) & 1.171 & .267 & & 4.837 & .000 \\
\hline & Election phase processes (X2) & .766 & .070 & .663 & 10.919 & .000 \\
\hline
\end{tabular}

Table 1: Coefficients of Election Phase Processes

a. Dependent Variable: Political Stability

Using the summary of Coefficients presented in Table 1, a linear regression model of the form, $Y=\alpha+\beta$ Xi can be fitted as follows:

$\mathrm{Y}=1.171+0.766 \mathrm{X} 2$ Equation 2

\subsubsection{Regression Analysis for Election Phase Processes}

Regression analysis was performed in order to determine whether the independent variable, election phase processes could be reliable for explaining the change in the dependent variable, political stability in East Africa region. The coefficients obtained indicate that the correlation coefficient $(R)$ between the independent variable and the political stability was 0.663 which is a positive correlation relationship. Table 2 shows a coefficient of determination $\left(\mathrm{R}^{2}\right)$ of 0.44 , which means that this variable alone can explain up to $44.0 \%$ of the variations in the dependent variable, political stability.

\begin{tabular}{|c|c|c|c|c|}
\hline Model & R & R Square & Adjusted R Square & $\begin{array}{c}\text { Std. Error of the } \\
\text { Estimate }\end{array}$ \\
\hline 1 & $.663^{\mathrm{a}}$ & .440 & .436 & .5318171 \\
\hline \multicolumn{4}{|c|}{ Table 2: Model Summary Showing Election Phase Processes }
\end{tabular}




\subsubsection{ANOVA for Election Phase Processes}

\section{a. Predictors: (Constant), Election phase processes}

The results of an ANOVA test performed on the variable election phase processes are summarized in Table 2 which shows that the variable has a P-value equal to 0.000 , indicating that the model is statistically significant in explaining the change in the dependent variable, considering that the P-value is less than 0.05 at the $95 \%$ level of confidence. Therefore, based on the empirical results presented in Table 2, the Alternative Hypothesis H2 is accepted and the null Hypothesis (H02) is rejected and a conclusion reached that, at 5\% level of significance, election phase processes significantly influence the political stability.

\begin{tabular}{|c|c|c|c|c|c|c|}
\hline \multicolumn{2}{|c|}{ Model } & $\begin{array}{c}\text { Sum of } \\
\text { Squares }\end{array}$ & Df & $\begin{array}{c}\text { Mean } \\
\text { Square }\end{array}$ & F & Sig. \\
\hline \multirow{3}{*}{1} & Regression & 34.528 & 1 & 34.528 & 119.214 & $.000^{\mathrm{a}}$ \\
\cline { 2 - 7 } & Residual & 44.023 & 52 & 0.29 & & \\
\cline { 2 - 7 } & Total & 78.551 & 53 & & & \\
\hline
\end{tabular}

Table 3: ANOVA for Election Phase Processes

a. Dependent Variable: Political Stability

c. Predictors: (Constant), Election Phase Processes

\section{Conclusions}

The objective was to determine the relationship between the election phase processes and political stability in the East African Community States. From this objective, it was hypothesized that there is no relationship between election phase processes and political stability in the East African Community States. The results of this study showed a positive statistically significant relationship between election phase processes and political stability in the East African Community States. Therefore, hypothesis H02: there is no significant relationship between election phase processes and political stability in the East African Community States was rejected and concluded that election phase processes have a significant effect on political stability. The findings therefore confirmed that election phase processes are a determinant of political stability in the East African Community States.

The findings confirm that there is a statistically significant influence of election phase processes and political stability in the East African Community States. A positive increase in election phase processes leads to an increase in political stability in the East African Community States. It can be concluded from this study that election phase processes were statistically significant in explaining political stability in the East African Community States. The study concludes that election administration has been effective and efficient as exercised in the EAC. The EAC laws and regulation on administration are adequate. Lastly the study concludes that there is no need to harmonize the implementation of the existing laws and regulation.

\section{Recommendations}

The following recommendations were made with reference to the study findings.

To enhance this, stakeholders should adopt an open-door approach that is decision making process. Research into issues in the program should be embraced in order to beef up on decision making process. To mitigate misappropriation, diversion and siphoning of East Africa Community state pre-election phases the stakeholder should do regular audit on the use of election law. They should further carry out monitoring and evaluation in order to ensure that monies were used for the intended projects. The government should sponsor frequent leadership conferences, seminars and workshops for leaders in order to fully polish their leadership in project management as well as group management skills.

\section{References}

i. Ayanda A. \& Odunayo B. (2015) Comparative Study of Presidential Elections in Nigeria Global. Journal of Human Social Sciences: F Political Science.

ii. Acemoglu, D. and Robinson, J. (2010). Why Did the West Extend the Franchise?Democracy, Inequality, and Growth in Historical Perspective, Quarterly Journal of Economics 115, 1167-1199.

iii. Acemoglu, D. and Robinson, J., (2016). Economic Backwardness in Political Perspective,American Political Science Review 100, 115-131.

iv. Ades, A.and Di Tella, R. (2009). Rents, Competition, and Corruption, American Economic Review 89, 982-983.

v. Aila. F \& Ombok, B. (2015). Validating Measures in Business Research: Practical Implications.International Journal of Science and Engineering. 1(9), 11-19.

vi. Ake, C. (2005). Socio Political Approaches and Policies for Sustainable Development in Africa. A paper delivered at the Annual Meeting Symposium of the African Development Banks, Abuja.

vii. Albertyn, C, Hassim, S and Meintjes S. (2012). Women's participation in electoral processes: South Africa in global perspective, in EISA op cit, pp 17-26.

viii. Aubyn, F. and Abdallah, M. (2013). Sustaining Peace and Stability: Appraising the Role of the National Election Security Task Force in the 2012 Elections. Journal of African Elections, Vol. 12, No. 2, 132-153.

ix. Baets, W. (2011). Leadership and Public Governance: Complexity, uncertainty and

x. Bass, B. M. \& Bass, R. (2008). Handbook of leadership theory, research and application. New York: Free Press 
xi. Bekoe, D. (2010). Trends in Electoral Violence in Sub-Saharan Africa, Washington, D.C.: United States Institute of Peace (USIP).

xii. Benoit, K. (2014) 'Models of Electoral System Change', Electoral Studies 23(3): 363-389.

xiii. Birch, S. (2010). Patterns of Electoral Malpractice. Working Paper No.4. Project on Malpractice in New and Semi-Democracies. University of Essex.

xiv. Blais, A., Massicotte, L., (2010). Electoral systems. In: LeDuc, L, Niemi, R.G., Norris, P. (Eds.), Comparing Democracies: Elections and Voting in Global Perspective. Laurence LeDuc, Sage, Thousand Oaks, CA, p. 49-82.

xv. Blau, D \& Adrian, B. (2008). Electoral Reform in the UK: A Veto-Player Analysis. In André Blais (ed.). To Keep or To Change First Past the Post? The Politics of Electoral Reform. Oxford: Oxford University Press, p. 61-89.

xvi. Blomme, R. J., Kodden, B. \& Suffolk, A. B. (2015). Leadership theories and the concept of work engagement: Creating a conceptual framework for management implications and research. Journal of management and organizational behaviors, 21 (2), 125-144.

xvii. Boix, C. and Milan, S. (2009). Non - tyrannical Autocracies. Paper presented at the UCLA Comparative Politics Seminar.

xviii. Booth, D. (2011). Governance for development in Africa: building on what works.

xix. Bratton, M. (2010) 'Anchoring the "D-Word" in Africa', Journal of Democracy, 21, 4, p. 108.

xx. Bratton, M. (2008), Vote Buying and Violence in Nigerian Election Campaigns, in: Electoral Studies, 27, 621-632.

xxi. Brooks, C. (2011). Introductory Econometrics for Finance. 2nd Ed). Cambridge: Cambridge University Press,

xxii. Bryman, A. (2011). Social Research Methods. New York: Oxford Publishers

xxiii. Bryman, A., \& Bell, E. (2009). Business Research Methods. Oxford: Oxford University Press.

xxiv. Burns, J. M. (2008). Leadership. New York, NY: Harper \& Row.

xxv. Burns, R, A., \& Burns, R. (2012). Business Research Methods and Statistics using SPSS. London: Sage Publications Ltd

xxvi. Chang, E. (2008). Electoral Incentives and Budgetary Spending: Rethinking the Role of Political. New York, NY: Harper \& Row. Cheeseman, N. (2014). Democracy in Africa: Successes, Failures, and the Struggle for Political Reform. Cambridge University Press.

xxvii. Clionadh, R. Roudabeh. K, McKnight. J \& James.M. (2016). Armed conflict location and event data set country report on Burundi crisis p.1-5

xxviii. Cooper, D. \& Schindler, P. (2011). Business Research Methods. New York: McGraw Hill.

xxix. Cronbach, L.J. (1990). Essentials of Psychological Testing, 5th Ed. New York.

xxx. Cyert, R. M., \& March, J. G. (2013). A behavioral theory of the firm. NJ: Englewood Cliffs.

xxxi. Dailon, R. (2011). Statistical Design and Analysis of Experiments for Development Research, Iowa: Brown publishing.

xxxii. Damania, R. and Bulte, E. (2013). Resources for Sale: Corruption, Democracy and the Natural Resource Curse, Mimeo, University of Adelaide. Democratization 13(4): 584-604.

xxxiii. Davis, J. S. (2011). Challenging governance theory: From network to hegemony. New

xxxiv. Denhardt, J.V, \& Denhardt, R. B. (2003). The new public service: Serving, not steering.

xxxv. Diamond, L. (2009). Developing Democracy Toward Consolidation. Baltimore: Johns distribution. Journal of Modern African Studies, 41(3), 339-370.

xxxvi. EISA, (2012). Pre-Election Assessment Mission to Ghana: Report, unpublished.

xxxvii. Election Commission of India (2014), Proposed Electoral Reforms, New Delhi: Nirwachan Sadan.

xxxviii. Election Commission of India (2009), Model Code of Conduct for the Guidance of Political Parties and Candidates. New Delhi Nirwachan Sadan.

xxxix. Election Expenses Act, (2010), [www] http:// www.parliament.go.tz/ Polis/ PAMS/ Docs/ 6-2010.pdf [PDF document, opens new window] (accessed 24 May 2016).

xl. Elections in Burundi, (2015). Moment of Truth Crisis Group Africa Report N²24, 17 April.

xli. European Union Election Observation Mission (2015). Final Report of the 2015 General Elections in the United Republic of Tanzania. Pages 1-10.

xlii. Fearon, J. D., \& Laitin, D. D. (2013). Ethnicity, insurgency, and civil war. American Political Science Review, 97(1), 75-90.

xliii. Frantz, E. and Geddes, B., (2013). 'Latin America's authoritarian drift: The threat from the populist left', Journal of Democracy, 24/ 3 pp. 18-32

xliv. Freeman, R. E. (2010). Strategic Management: A Stakeholder Approach. Cambridge University Press, New York.

xlv. Fox J, Shotts KW (2009). Delegates or trustees? A theory of political accountability. J. Polit. 71(4):1225-37

xlvi. Gastil, J. (2014). A definition and illustration of democratic leadership. Human Relations, 47, pp 504-521.

xlvii. Ghauri, P. Gronhaug, K. (2010).Research Methods in Business Studies: A Practical

xlviii. Gill, M. S. (2009). Electoral Systems in India. Available http:/ / eci.nic.in/ eci_main/ eci_publications/ books/ miscell/ ESI-III.pdf.Last viewed on 27th October 2016.

xlix. Global Peace Index, (2015). Institute of Economics and Peace.

1. Grofman, B, S. Bowler, and Blais, A. (2009). Duverger's Law of Plurality Voting: The Logic of Party Competition in Canada, India, the United Kingdom and the United States. New York: Springer.

li. Gujarat, D. N. (2011). Basic Econometrics, (6th Ed.). Boston. The McGraw-Hill Companies.

lii. IFES, (2015). Residential Elections Act 2000.www.ulii.org.Retrieved 2016-02-08.Instrumental variables approach. Journal of Political Economy, 112(4).725-753. 
liii. International Institute for Democracy and Electoral Assistance (International IDEA) (2017). The Global State of Democracy2017: Exploring Democracy's Resilience (Stockholm: International IDEA, 2017),

liv. IPU, (2015). Electoral system. International Conflict Resolution No. 2. Washington, DC: National Academy Press.

lv. Judge, T. A., \& Piccolo, R. F. (2014). Transformational and transactional leadership: Ameta-analytic test of their relative validity. Journal of Applied Psychology, 8 (5), 755 -768.

lvi. Kadima, D and Matlosa, K (2009) The Roles of Regional Organizations in Elections in Africa

lvii. Kapur AC (2009). Principles of Political Science New Delhi: S Chand.

lviii. Kathurima, M. (2011). The Kenya Electoral system. ALRAESA Workshop on Model Electoral Laws Swakopmund, Namibia, 26-27July 2011

lix. Katz, R.S. (2015). Why are there so many (or so few) electoral reforms? In: Michael Gallagher and Vcx

lx. Khamisi, J. (2011). The politics of betrayal: Diary of a Kenyan Legislator. USA: Trafford Publishing. Leiden: Koninklijke Brill NV.

lxi. Kilonzo, S. (2009). "Ethnic Minorities Wedged Up in Post-Election Violence in Kenya: A Lesson for African Governments." Critical Arts: A South-North Journal of Cultural \& Media Studies 23, no. 2 245-251.

lxii. Kombo, D. K., \& Tromp, D. L. (2011). Proposal and Thesis Writing; An Introduction. Nairobi: Paulines Publications Africa.

lxiii. Kothari, C.R. (2011). Research Methodology; Methods and Techniques. New Delhi: New Age International Publishers.

lxiv. Kothari, C.R. (2004). Research Methodology: Methods and Techniques, New Delhi: New age International, Pp.3152

lxv. Kribat, M., Burton, B., \& Crawford, L. (2013). Evidence on the nature, extend and determinants of disclosures in Libyan banks' annual reports. Journal of Accounting in Emerging Economies, 3(2), 88-114.

lxvi. Kura BY (2014). Clientale Democracy: Political Party Funding and Candidate Selection in Nigeria. African Journal of Political Science and International Relations.

lxvii. Lamin, Abdul Rahaman (2011), West Africa in Context: Elections and Challenges of Democratic Governance, in: Journal of African Elections, 10, 2.

lxviii. Lavrakas, P. J. (2013). Encyclopedia of Survey Research Methods. (Volume 1). Thousand Oaks, CA: Sage Publications.

lxix. Lindberg, S. I. (2010). What Accountability Pressures Do MPs in Africa Face and How Do they respond? Evidence from Ghana. Journal of Modern African Studies, 48(1), 117-142. http:/ / dx.doi.org/ 10.1017/ S0022278X09990243

lxx. Likert, R. (1832). A Technique for measurement of attitudes. Archives of Psychology No. 40.

lxxi. Lindberg, S. (2010). Some evidence on the demand side of private-public goods provision by MPs.

lxxii. Lwaitama, A. (2012). Political Parties and Citizens' Participation in EACIntegration. Synthesis of the Findings Drawn from Five Country Studies. In Youth, Democracy and Legal Reform Processes: Articles from FES Political Handbooks 2013, 2012.

lxxiii. Marshall, C., \& Rossman, G.B. (2010). Designing qualitative research. New York: Sage Publications

lxxiv. Matlosa, K \& Sello, N, 'Political parties and democratization in Lesotho', EISA Research Report No. 23, (Johannesburg: EISA, 2005), p. 24.

lxxv. Mbaku JM (2010). Bureaucratic and Political Corruption in Africa: The Public Choice Perspective Malabar: Kreiger Publishing.

lxxvi. McGowan, P.J. (2014). African military coups d'etat, 1956-2001: Frequency, trends and

lxxvii. McQuail, D. (2015). McQuail’s Mass Communication Theory, Sage Publication, London.

lxxviii. Michael Krennerich (2012). Germany: The Original Mixed Member Proportional System. http:/ / www.idea.int/ esd/ upload/ germany.pdf.

lxxix. Miller, M.L. (1986). Reliability and Validity in Qualitative Research. Beverly Hills: sage Publication.

lxxx. Mudde, C., (2013). The 2012 Stein Rokkan Lecture. Three decades of populist radical right parties in Western Europe: So, what?', European Journal of Political Research, 52/ 1, pp. 1-19

lxxxi. Mudde, C. and Kaltwasser, C. R., (2013). 'Populism', in M. Freeden and M. Stears (eds), OxfordHandbook of Political Ideologies (Oxford: Oxford University Press)

lxxxii. Mugenda, O. M., \& Mugenda, A. G. (2008). Research methods: Quantitative and qualitative approaches. NairobiKenya: Acts Press.

lxxxiii. Mugenda, O.M., \& Mugenda, A.G. (2013). Research methods. Nairobi: McMillan Publishers.

lxxxiv. Muhula, R. (2009). Horizontal Inequalities and Ethno-regional politics in Kenya. Kenya Studies Review: 1(1) 85105.

lxxxv. Munday, J. (2009). Introducing translation studies: Theories and applications. New York: Routledge

lxxxvi. Mukandala, R. \& Killian, B. (2004). Political Cooperation in East Africa, in S.S.

lxxxvii. Mutua Kioko.P. (2010). A Study on the Post-Election Violence in Kenya, an International Law Perspective Ph.D thesis p.20-30

lxxxviii. Mwangola, M. S. (2013). Leaders of tomorrow? The youth and democratization in Kenya in Kenya: the struggle for democracy. London and New York: ZED books

lxxxix. National Electoral Commission, (2010). Electoral Code of Conduct for the Presidential, Parliamentary and Councilors. Elections.

xc. National Electoral Commission, (2010). Guidelines for local and international Election observers. 
xci. Ngari, C. (2017). Relationship between Workplace Chronemic Culture and Employee Performance among Service State Corporations in Kenya.

xcii. Ngowi, H. P. (2009). Economic development and change in Tanzania since independence: The political leadership factors. African Journal of Political Science and International Relations, 3(4), 259-267.

xciii. Nicole. S and Monroe, E. (2009). Media, Elections and Political Violence in Eastern Africa: Towards a Comparative Framework. University of Oxford Center for Global Communication Studies, Annenberg School for Communication.p1-25

xciv. Norman, S. King (2013). African development bailout: Striking a balance between religion, peace and tranquility. International Journal Social Science Research. Vol.2 (5), 55-65

xcv. Norris. P, (2006). Revisiting the theories of the state first developed by Marx, Engels and especially Lenin in his work. The State and Revolution.

xcvi. Norris, P. (2002). Democratic Phoenix: Reinventing Political Activism. Cambridge: Cambridge University Press. Oaks, CA: Sage Publications, Inc.

xcvii. Obazee G (2014) The Effects of Corruption on the Inflow of Foreign Direct Investment into Ten Sub-Saharan African Countries: Using Ghana and Nigeria as Discussion Points PhD Thesis submitted to the Faculty of Wilmington University

xcviii. Obi, C. (2008), International Election Observer Missions and the Promotion of Democracy: Some Lessons from Nigeria's 2007 Elections, in: Politikon, 35, 1, 69-86.

xcix. Odhiambo, F. (2009) The 2007 General Elections in Kenya: Electoral Laws and Processes. Journal of African Elections 7 (2), pp.113-123

c. Ogbeidi, M. M. (2012). Political leadership and corruption in Nigeria since 1960: A socioeconomic analysis. Journal of Nigerian Studies, 1(2), 1-25.

ci. Olorunmola A (2016). Cost of Politics in Nigeria Westminster Foundation for Democracy

cii. Olopade, D. (2014). The bright continent and making change in modern Africa. London: Duckworth overlook

ciii. Omilusi M, Adu AOP (2016). Party Politics and Democratic Governance in Nigeria: Historical Perspective, International Journal of Multidisciplinary Academic Research Organization for Economic Countries and Development (OECD) Publication.

civ. Oyedele, O. A. (2012). The challenges of infrastructure development in democratic governance. Constructive Economics and Management,1(6119), 1-15. Retrieved from www.fig.net/ TSOIC

cv. Oso, W. \& Onen, D. (2011). A General Guide to Writing Research Proposal and Report; Handbook for Beginning Researchers. Nairobi: Jomo Kenyatta Foundation.

cvi. Parliamentary Education Office, (2009). Fact sheets for students http://www. peo.gov.au/ students/ fss/ index.html.

cvii. Patton, M. Q. (2009). Qualitative evaluation and research methods (3rd ed.). Thousand Pawell,

cviii. Ponzio, Richard. (2011). Democratic peacebuilding: aiding Afghanistan and other fragile states. Oxford; New York: Oxford University Press.

cix. Reno, William (2011). Warfare in independent Africa. Cambridge; New York: Cambridge University Press.

cx. Resnick, D. and Casale, D. (2011). The Political Participation of Africa's Youth. Turnout, Partisanship, and Protest. Working Paper No. 2011/ 56. Helsinki: UNU-WIDER.

cxi. Reynolds A \& Carey J.M. (2012), 'Getting elections wrong', Journal of Democracy, 23, 1, 2012.

cxii. Reynolds, A. (2009) Electoral systems choices for South Africa beyond 1999, in EISA (ed) Electoral Systems.

cxiii. Robert, Henry M.; et al. (2011). Robert's Rules of Order Newly Revised (11th ed.). Philadelphia, PA: Da Capo Press. pp. 438-446.

cxiv. Rotberg, R. (2012). Transformative Political Leadership: Making a Difference in the Developing World. Chicago and London: University of Chicago Press.

cxv. Royston, J. P. (2012). An extension of Shapiro and Wilk's W test for normality to large samples. Applied Statistics, 115-124.

cxvi. Saboe, K. N., Taing, M. U., Way, J. O., \& Johnson. R. E. (2015). Examining the unique mediators that underlie the effect of different dimensions of transformational leadership. Journal of leadership and organizational studies, 22 (2), $175-186$.

cxvii. Saunders, M., Lewis, P., \& Thornhill, A. (2009). Research methods for business students. (5th Ed.). London: Prentice Hall.

cxviii. Schutt, R.K. (2015). Investigating the Social World: The Process and Practice of Research. London: Sage Publications

cxix. Sekaran, U. \& Bougie, R. (2011). Research Methods for Business: A Skill Building Approach. Delhi: Aggarwal printing press,

cxx. Shri Mohan Singh, M.P. (2011). The constitution Amendment Bill. As introduced in the Rajya Sabha on 5thAugust 2011. P.2.

cxxi. Shriberg, D. \& Shriberg, A. (2011). Practicing leadership: Principles and applications. 4th (Ed.). U.S.A: Thompson digital.

cxxii. Shugart, M.S. (2005) 'Comparative electoral systems research: the maturation of a field and new challenges ahead', in M. Gallagher and P. Mitchell (eds.) The Politics of Electoral Systems, Oxford: Oxford University Press, 25-56.

cxxiii. Smith, D. (2011). The re-demarcation and reapportionment of parliamentary constituencies inGhana. CDD-Ghana Briefing Papers, 10(2), 1-12. 
cxxiv. Smith, E. R., \& Conrey, F. R. (2010). Mental representations are states, not things: Implications

for implicit and explicit measurement. In B. Wittenbrink \& N. Schwarz (Eds.), Implicit measures of attitudes (pp. 247-264). New York: Guilford Press

cxxv. Stokes SC (2013). Clientelism in Oxford Handbooks Online the Centre for Public Policy Alternatives (CPPA) Presidential Election Outcome: Analyses and Implications, Transparency International Report.

cxxvi. Suhas P. (2012). Elections in India Prestige deriving from practice. Institute for Research and Debate on Governance. Paris: Charles Léopold Mayer Publishing House.

cxxvii. Teorell, J \&Lindstedt, C (2010). Measuring electoral systems. Political Research Quarterly, Vol. 63, No2. (pp. 434448).

cxxviii. Thad E. H. (2012). Primer on the U.S. Election System pp.3-25. University of Utah Salt Lake City, Utah, USA

cxxix. The National Electoral Commission of Tanzania, (2010) The electoral process in East Africa Tanzania's perspective. The National Elections Act, Cap 343, the Local Authorities Act, Cap 292 pp.2-22

cxxx. Touliatos, J., \& Compton, N. H. (2013). Research methods in human ecology/ home economics. Ames: Iowa State University Press

cxxxi. Tucker, B.A., \& Russell, R.F. (2014). The influence of the transformational leader. Journal of Leadership \&Organizational Studies, 10(4), 103-111.

cxxxii. Uddin, M. N. \& Hamiduzzan, M. (2009). The philosophy of Science in Social Research. The Journal of International Social Research, 2(6).

cxxxiii. Uganda Law reform commission, (2011). Country report on Electoral systems in Uganda.

cxxxiv. Ukase P. (2015) Political Parties and Election / Campaign Financing in Nigeria: Interrogating the General Elections.

cxxxv. United States Department of State Bureau of Democracy, Human Rights and Labor (2015). Country Reports on Human Rights Practices. p 18-22

cxxxvi. USAID, UKAID (2015). Still Above the Ceiling: A Report on Campaign Finance and Use of State Administrative Resources in the Presidential Election, Centre for Social Justice.

cxxxvii. Wagner, Wolfgang, and Sofie Dreef. (2013). "Ethnic Composition and Electoral System Design: Demographic Context Conditions for Post-conflict Elections." Ethnopolitics:1-20. doi: 10.1080/ 17449057.2013.793883.

cxxxviii. Xu, Z. and Li, H. (2008) 'Political freedom, economic freedom, and income convergence: Do stages of economic development matter?', Public Choice, 135, pp. 183-205.

cxxxix. Yu, H., Leithwood, K., \& Jantzi, D. (2012). The effects of transformational leadership on teachers' commitment to change in Hong Kong. Journal of Educational Administration, 40(4), 368-89.

cxl. Zikmund, G.W., Babin, B.J., Carr, C.J., \& Griffin, M. (2010). Business research methods. (8th ed.). South-Western, Cengage Learning. 